\title{
SCREENING FOR NEW ANTITRICHOMONAL SUBSTANCES OF MICROBIAL ORIGIN AND ANTITRICHOMONAL ACTIVITY OF TRICHOSTATIN A
}

\author{
Kazuhiko Otoguro, Ruiko ÖIwa, Yuzuru IwaI, \\ HaRuo TANaKa and Satoshi OMURA* \\ The Kitasato Institute, and School of Pharmaceutical Sciences, Kitasato University, \\ Minato-ku, Tokyo 108, Japan
}

(Received for publication October 14, 1987)

\begin{abstract}
In vitro and in vivo screening methods for new antitrichomonal substances were established. Primary screening is based on in vitro antitrichomonal activities of culture broths of actinomycetes isolated from soil. With secondary screening, after crude materials obtained from the cultured broths were administered orally to mice, excretion of antitrichomonal activity into urine was examined. Tertiary screening was done by examining therapeutic activity for experimental trichomoniasis in mice with Trichomonas foetus.

Using the screening systems, a new antibiotic (setamycin)-producing strain was picked out among about six thousands soil isolates, and the therapeutic efficacy of KM-3851, which was identified as trichostatin $\mathrm{A}$, was found. It was active against $T$. foetus both in vitro and in vivo.
\end{abstract}

Many kinds of parasitic diseases remain to be conquered. There are relatively few antiparasitic agents compared with the many antibiotics available for the treatment of bacterial infections.

Trichomoniasis, one of parasitic diseases, is sexually transmitted. Systemic agents are desirable for chemotherapy of the sexually transmitted disease. In 1959, metronidazole was marketed as the first systemic antitrichomonal agent. It was selected for in vitro and in vivo antitrichomonal activity among about 150 nitroheterocyclic compounds synthesized on the basis of the structure of azomycin which was the first nitroheterocyclic antibiotic possessing antiprotozoal activity. ${ }^{1,2)}$ Recently, however, in vivo resistance to metronidazole and its carcinogenicity and mutagenicity have been reported..$^{3)}$

So, we tried to develop a screening method for new antitrichomonal agents from fermented broths of microorganisms to find superior antitrichomonal drugs.

In this paper we present the new in vitro and in vivo screening methods with evidence for its applicability and the results of the practical screening using the methods.

\section{Materials and Methods}

\section{Organisms and Media}

A strain of Trichomonas foetus provided from Merck Sharp \& Dohme Research Laboratories, U.S.A. was maintained at $37^{\circ} \mathrm{C}$ in DIAMono's medium ${ }^{4}$ supplemented with $10 \%$ heat-inactivated calf serum, $100 \mathrm{U} / \mathrm{ml}$ of benzylpenicillin and $1.0 \mathrm{mg} / \mathrm{ml}$ of streptomycin sulfate, using 48-hour transfers, and used as a test organism.

Trichosel Broth (BBL) supplemented with $5 \%$ heat-inactivated calf serum, $100 \mathrm{v} / \mathrm{ml}$ of benzylpenicillin and $1.0 \mathrm{mg} / \mathrm{ml}$ of streptomycin sulfate, was used for in vitro assay of antitrichomonal activity.

ASAMI's medium, ${ }^{52}$ SYS medium ${ }^{6)}$ and Vf bouillon medium ${ }^{72}$ which were supplemented with $5 \%$ heat-inactivated calf serum, $100 \mathrm{U} / \mathrm{ml}$ of benzylpenicillin and $1.0 \mathrm{mg} / \mathrm{ml}$ of streptomycin sulfate were also used for growth test. 
Mice (ICR) of female and 19 25 $\mathrm{g}$ in weight were obtained from commercial sources. Water and feed were provided ad libitum.

Primary Screening by In Vitro Assay for Antitrichomonal Activity

In the primary screening, the inhibitory activities of cultured broths of soil actinomycetes against $T$. foetus were assayed. An aliquot $(200 \mu \mathrm{l})$ of a cultured broth of an actinomycete, $100 \mu \mathrm{l}$ of heatinactivated calf serum containing $2,000 \mathrm{U} / \mathrm{ml}$ of benzylpenicillin and $20 \mathrm{mg} / \mathrm{ml}$ of streptomycin sulfate were added to $1.6 \mathrm{ml}$ of Trichosel Broth, and then $100 \mu$ lof a diluted cell suspension $\left(2 \times 10^{5} \mathrm{cells} / \mathrm{ml}\right)$ prepared from an actively multiplying $T$. foetus culture was delivered into the above medium. The number of the trichomonads to be inoculated was determined with hemocytometer count. After incubation for 48 hours at $37^{\circ} \mathrm{C}$, the number of $T$. foetus cells was counted with a hemocytometer. The cultured broths showing reduction of the number over $50 \%$ were selected for the secondary screening.

\section{Secondary Screening by Urine Excretion Test}

Water extract of dried culture filtrate combined with $\mathrm{MeOH}$ extract of mycelium was used as a sample preparation for the test. Each $0.5 \mathrm{ml}$ of a sample solution possessing in vitro activity equivalent to that of $200 \sim 1,000 \mu \mathrm{g} / \mathrm{ml}$ of metronidazole was administered orally to mice, and then urine was collected for 4 hours. The antitrichomonal activity of the urine was determined by the above in vitro assay method with $T$. foetus.

\section{Tertiary Screening by In Vivo Assay for Antitrichomonal Activity}

A culture of $T$. foetus grown in the Trichosel Broth was inoculated intraperitoneally into mice and reisolated from the mice. The procedures were repeated several times prior to in vivo experiment to increase its virulence and infectivity.

A mouse was inoculated intraperitoneally with $1 \mathrm{ml}$ of a 48-hour culture containing about two million $T$. foetus immediately after the oral administration of the test compound as described by CuCKLer et al. ${ }^{8)}$ The drugs were suspended in $0.5 \%$ Methocel (methylcellulose) or distilled water. Oral treatment was given once daily for 4 successive days. The experiments were terminated at 7 days after the mice were inoculated with trichomonads. The criteria of antitrichomonal efficacy were based upon the presence of living trichomonads in peritoneal fluid. The living trichomonads were detected microscopically in a 48-hour culture of a washing fluid with sterilized physiological saline solution from infected abdominal cavity in the treated mice.

Chemicals

Metronidazole was obtained from Merck Sharp \& Dohme Research Laboratories, U.S.A., trichostatin A was prepared from the fermented broth of the strain KM-3851 in our laboratory as described by TSUII et al. ${ }^{92}$

\section{Results and Discussion}

\section{Growth of T. foetus in Various Media}

Fig. 1 shows the growth of $T$. foetus in various media tested. Among them DiamonD's medium, AsAm's medium and Trichosel Broth supported good growth of the organism. Number of the cells reached maximum after incubation for 48 hours with DiAmond's medium and Trichosel Broth, and after 36 hours with AsAMI's medium. Trichosel Broth among them was used as in vitro assay medium because it was commercially available. With SYS and Vf bouillon media, the growth rate was relatively slow.

\section{Urine Excretion Test with Metronidazole}

To investigate the absorption and excretion of metronidazole as model antitrichomonal agent in mice, urine was collected for 4 hours after metronidazole was administered orally, and then the 
Fig. 1. Growth of Trichomonas foetus in various media.

-: Dramond's medium, $O$ : Trichosel Broth, $\triangle$ : AsAMI's medium, $\Delta$ : SYS medium, $\square$ : Vf bouillon medium.

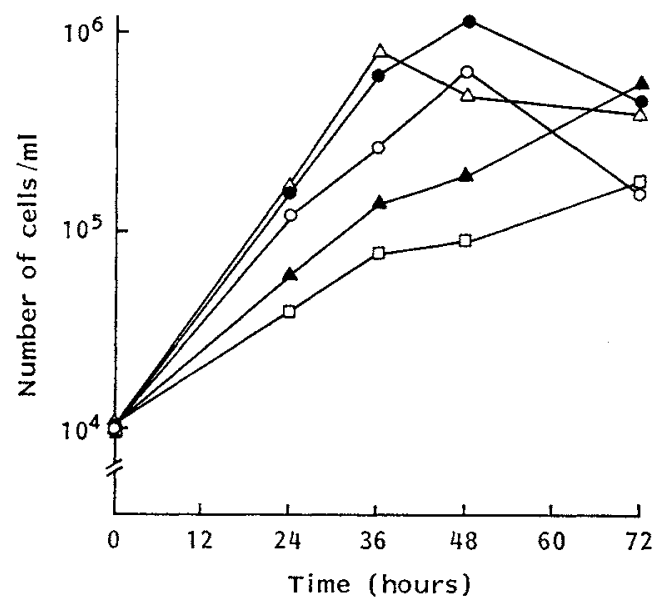

Media was inoculated with $1 \times 10^{4}$ cells $/ \mathrm{ml}$ of the organism and incubated at $37^{\circ} \mathrm{C}$ without shaking. antitrichomonal activity of the urine was determined. As shown in Table 1, the urine preparations from mice to which $50 \sim 200 \mu \mathrm{g}$ of metronidazole was administered showed a significant antitrichomonal activity against $T$. foetus. Considering these results, in the urine excretion test

Table 1. The antitrichomonal activities of urine preparations from mice to which metronidazole was administered.

\begin{tabular}{ccc}
\hline $\begin{array}{c}\text { The amount of } \\
\text { metronidazole } \\
\text { administered } \\
\text { to mice } \\
(\mu \mathrm{g} / \text { mouse })\end{array}$ & $\begin{array}{c}\text { Dilution } \\
\text { rate } \\
\text { of urine }\end{array}$ & $\begin{array}{c}\text { Antitrichomonal } \\
\text { activity } \\
\text { (inhibition \%) }\end{array}$ \\
\hline 50 & 1 & 79 \\
& $1 / 2$ & 35 \\
100 & 1 & 87 \\
& $1 / 2$ & 79 \\
200 & 1 & 99 \\
& $1 / 2$ & 83 \\
& $1 / 4$ & 53 \\
\hline
\end{tabular}

Scheme 1. Results of screening for antitrichomonal antibiotics.

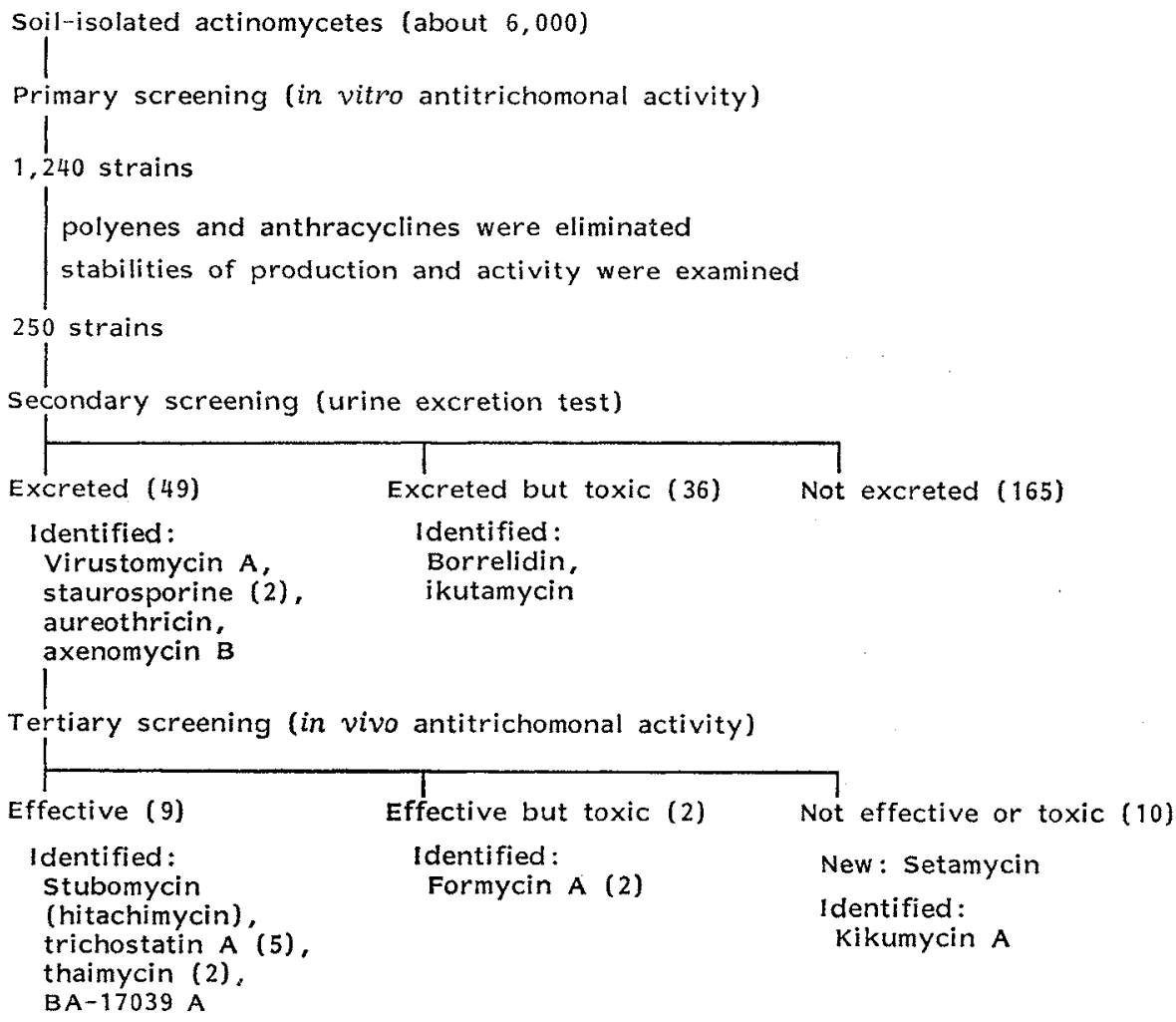

A number in the parenthesis indicates a number of strains. 
of cultured broths of soil isolates showing in vitro antitrichomonal activity, the amount of cultured broth showing the activity equivalent to $100 \sim 500 \mu \mathrm{g}$ of metronidazole was administered orally to mice.

\section{Results of this Screening Program}

Broth filtrates of about 6,000 strains of actinomycete soil isolates were submitted to this screening program. As shown in Scheme 1, 1,240 strains among them passed the primary screening and 49 strains passed the secondary screening. Finally, only 9 strains passed the tertiary screening. However, the active products from all passed strains were identified with known antibiotics. Although a new antibiotic setamycin was discovered in this screening work.

Setamycin (KM-6054) is active in vitro against trichomonads, some fungi and Gram-positive bacteria. However, the antibiotic was toxic in mice when it was orally administered at the dose over $10 \mathrm{mg} / \mathrm{kg}$, and was not effective to T. foetus in mice when it was administered at the dose below 10 $\mathrm{mg} / \mathrm{kg}$. The taxonomy, isolation and properties have been reported by ÖMURA et al. ${ }^{10,11)}$ The producing organism, strain KM-6054, was found to be a new genus of the order Actinomycetales, and named Kitasatosporia setae gen. nov. sp. nov. ${ }^{12}$ Recently, the structure was elucidated as shown in Fig. 2.13)

The antitrichomonal activities of trichostatin A, BA-17039A, stubomycin (hitachimycin), formycin A, kikumycin A, virustomycin A, staurosporine and aureothricin (Fig. 3) among twelve antibiotics identified in this screening work (Scheme 1) have never been known while those of the other four antibiotics (borrelidin, ${ }^{14,15)}$ axenomycin $\mathbf{B},{ }^{16,17)}$ thaimycin ${ }^{18)}$ and ikutamycin ${ }^{19}$ ) have been reported. Hitachimycin is a 19-membered lactam antibiotic ${ }^{20)}$ isolated from a culture broth of an actinomycete strain in this screening program. ${ }^{21}$ After that hitachimycin was found to be identical with the antitumor antibiotic stubomycin. ${ }^{22)}$ It is active against Gram-positive bacteria, some fungi, mycoplasmas, and HeLa cells besides trichomonads. ${ }^{21,22}$

Virustomycin $\mathrm{A}$ was found as an antivirus antibiotic in our laboratory. It is active against trichomonads and various RNA and DNA viruses and weakely active against some fungi as reported previously. ${ }^{23,242}$ The structure and mode of action against $T$. foetus have been reported previously

Fig. 2. Structures of setamycin and virustomycin A.<smiles>COC(=C/C(C)=C\C(C)C(O)C(C)C/C(C)=C/C=C/C(OC)C(OC(=O)/C=C/C(=O)NC1=C(O)CCC1=O)C(C)C(O)C(C)C1(O)CC(OC(=O)/C=C/C(=O)NC2C(=O)CCC2O)C(C)C(C(C)C)O1)C(C)C</smiles>

Setamycin<smiles>C/C=C/C=C(\C)CC(C)C(O)C(CC)C(O)C(C)/C=C(C)/C=C(/C(=O)OC1CC(OC(=O)/C=C/C(=O)NC2=C(O)CCC2=O)C2OC(/C=C/C)O[C@@](O)(C(C)C(O)C1C)C(C)C2O)C(C)C</smiles>

Virustomycin A 
Fig. 3. Structures of stubomycin (hitachimycin), trichostatin A, formycin A, kikumycin A, staurosporine and aureothricin.<smiles>COC1CC(/C=C(C)\C=C\C=C\C(=O)NC(C/C=C/CCC(O)CC(=O)C2=C(O)C(OC)CC2)c2ccccc2)C1</smiles>

Stubomycin (hitachimycin)<smiles></smiles>

Formycin A

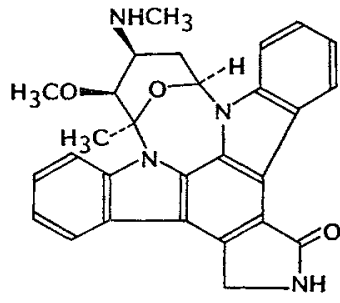

Staurosporine<smiles>CC(/C=C/C(=O)NO)=C\C(C)C(=O)c1ccc(N(C)C)cc1</smiles>

Trichostatin A<smiles>N=C(N)/C=C/NC(=O)c1cc(NC(=O)C2CCC(=N)N2)c[nH]1</smiles>

Kikumycin $\mathrm{A}$

Aureothricin

by the authors (Fig. 2). ${ }^{24,25)}$

Trichostatin A is a natural hydroxamic acid active against trichophytons and some other fungi. ${ }^{9)}$ BA-17039-A is active against HeLa cell, S-180 and adenocarcinoma $755 . .^{28)}$ It is a peptide antibiotic although the structure has not been elucidated. Formycin $\mathrm{A}$ is a $C$-nucleoside antibiotic, active against Gram-positive and Gramnegative bacteria and tumor. ${ }^{27},{ }^{28)}$ Kikumycin A is a pyrrol-amide antibiotic, active against Grampositive and Gram-negative bacteria. ${ }^{29,30)}$ Staurosporine is a microbial alkaloid possessing

Table 2. Antitrichomonal activities of metronidazole and the antibiotics whose antitrichomonal activities were found in this screening work.

\begin{tabular}{lc}
\hline \multicolumn{1}{c}{ Compound } & MIC $(\mu \mathrm{g} / \mathrm{ml})$ \\
\hline Metronidazole & 1 \\
Setamycin & 1.25 \\
Stubomycin (Hitachimycin) & 2 \\
Virustomycin A & 1.6 \\
Trichostatin A & 0.05 \\
BA-17039-A & 1.25 \\
Formycin A & 12.5 \\
Kikumycin A & 25 \\
Staurosporine & 2.5 \\
Aureothricin & 1 \\
\hline
\end{tabular}


Table 3. Therapeutic efficacy of trichostatin A and metronidazole on experimental trichomoniasis in mice.

\begin{tabular}{cccccc}
\hline Drug & $\begin{array}{c}\text { Daily dose } \\
(\mathrm{mg} / \mathrm{kg})\end{array}$ & $\begin{array}{c}\text { Objective } \\
\text { symptom }^{\mathrm{a}}\end{array}$ & $\begin{array}{c}\text { Suppressive } \\
\text { symptom }^{\mathrm{b}}\end{array}$ & $\begin{array}{c}\text { Non- } \\
\text { infection }^{c}\end{array}$ & $\begin{array}{c}\text { Cured } \\
(\%)\end{array}$ \\
\hline Trichostatin A & 100 & $2 / 6$ & 0 & $4 / 6$ & 67 \\
& 75 & $2 / 6$ & 0 & $4 / 6$ & 67 \\
& 50 & $4 / 6$ & 0 & $2 / 6$ & 33 \\
Metronidazole & 25 & $4 / 6$ & $1 / 6$ & $1 / 6$ & 17 \\
& 12.5 & $5 / 6$ & 0 & $6 / 6$ & 17 \\
& 100 & 0 & 0 & $6 / 6$ & 100 \\
Blank test & 75 & 0 & 0 & $4 / 6$ & 100 \\
& 50 & $2 / 6$ & 0 & $4 / 6$ & 67 \\
& 25 & $2 / 6$ & $1 / 6$ & $2 / 6$ & 67 \\
\hline
\end{tabular}

The method is described in the text. Number of mice; infected/used or cured/used.

a Formation of much peritoneal fuid was observed.

b Much peritoneal fluid was not formed, but living trichomonads were detected microscopically in a 48hour culture of washing fluid from infected abdominal cavity with sterilized physiological saline solution.

- No living trichomonads were detected.

some antifungal activities. The taxonomy, isolation, properties and structures have been reported by ŌMURA et al. ${ }^{31,32)}$ Aureothricin is a pyrrothine antibiotic, active against Gram-positive and Gramnegative bacteria and some fungi. ${ }^{33,34)}$

Table 2 shows the antitrichomonal activities of those antibiotics against $T$. foetus. Trichostatin A among them exhibited the strongest activity. The activity was stronger than that of metronidazole. So, we tried further in vivo experiment as described below.

\section{In Vivo Antitrichomonal Activity of Trichostatin $\mathrm{A}$}

The therapeutic efficacy of trichostatin A on experimental trichomoniasis in mice was examined compared with that of metronidazole. As shown in Table 3, trichostatin A exhibited moderate effect against peritoneal infections of $T$. foetus in mice when it was administered orally. These results suggest that trichostatin $\mathrm{A}$ might be useful as a topical trichomonacide although the activity was somewhat weak compared with that of metronidazole. Further investigations are necessary to evaluate the activities of trichostatin A against other protozoas.

\section{Acknowledgment}

The authors thank Mr. J. Horie, K. Kurumizawa, M. FuruYa and Y. Nakazato for their technical assistance. Particular thanks are due to Dr. H. B. Woodrufr for many helpful discussions and suggestions throughout this work.

\section{References}

1) Cosar, C. \& L. Julou: Activite de 1'(hydroxy-2'-ethyl)-1-methyl-2-nitro-5-imidazole vis-a'-vis des infections experimentales a' Trichomonas vaginalis. Ann. Inst. Pasteur Paris 96: 238 241, 1959

2) Nakamura, S. \& H. Umezawa: Structure of azomycin (2-nitro-imidazole). J. Antibiotics, Ser. A 8: 66,1955

3) Honigrerg, B. M.: Trichomonads of importance in human medicine. In Parasitic Protozoa. Ed., J. P. KREIER, pp. 275 454, Academic Press, New York, 1977

4) Diamond, L. S.: The establishment of various trichomonads of animal and man in axenic cultures. J. Parasitol. 43: 488 490, 1957 
5) ASAMI, K.: Physiological studies on T. vaginalis. Keio J. Med. 5: 169 190, 1956

6) IKeUCH, K.: Studies on the cultivation of Trichomonas vaginalis. J, Osaka City Med. Center 8: 853 867,1959

7) Magara, M.; E. Amino \& E. Yokouti: One method for the pure culture of T. vaginalis. Am. J. Trop. Med. Hyg. 2: $267 \sim 270,1953$

8) Cuckler, A.C.; C. M. Malanga \& J. Conroy: Therapeutic efficacy of new nitroimidazoles for experimental trichomoniasis, amebiasis and typanosomiasis. Am. J. Trop. Med. Hyg. 19: 916 925, 1970

9) Tsuji, N.; M. Kobayashi, K. Nagashima, Y. Wakisaka \& K. Kolzumi: A new antifungal antibiotic, trichostatin. J. Antibiotics 29:1 6, 1976

10) Ömura, S.; K. Otoguro, T. Nishikiori, R. Örwa \& Y. IwaI: Setamycin, a new antibiotic. J. Antibiotics 34: $1253 \sim 1256,1981$

11) Ömura, S.; Y. IWai, Y. Takahashi, K. Kojima, K. Otoguro \& R. Orwa: Type of diaminopimelic acid different in aerial and vegetative mycelia of setamycin-producing actinomycete KM-6054. J. Antibiotics 34: $1633 \sim 1634,1981$

12) Òmura, S.; Y. Takahashi, Y. Iwai \& H. Tanaka: Kitasatosporia, a new genus of the order Actinomycetales. J. Antibiotics 35: 1013 1019, 1982

13) Otoguro, K.; A. Nakagawa \& S. Ömura: Setamycin, a 16-membered macrolide antibiotic. Identification and nematocidal activity. J. Antibiotics 41:250 252, 1988

14) Berger, J.; L. M. JAMPOLSKY \& M. W. GoldBerg: Borrelidin, a new antibiotic with anti-borrelia activity and penicillin enhancement properties. Arch. Biochem. Biophys. 22: 476 478, 1949

15) Lumb, M.; P. E. Macey, J. Spyvee, J. M. Whitmarsh \& R. D. Wright: Isolation of vivomycin and borrelidin, two antibiotics with anti-viral activity, from a species of Streptomyces (C2989). Nature 206: $263 \sim 265,1965$

16) Bruna, C. D.; M. L. Ricciardi \& A. SANfilippo: Axenomycins, new cestocidal antibiotics. Antimicrob. Agents Chemother. 3: 708 710, 1973

17) Bianchi, M.; E. Cotta, G. Ferni, A. Grein, P. Julita, R. Mazzaleni \& C. Spalla: Axenomycins, new anthelmintic antiprotozoal and antifungal antibiotics, produced by Streptomyces lisandri nov. $\mathrm{sp}$. Arch. Microbiol. 98: 289 299, 1974

18) Cassinelli, G.; E. Cotta, G. D’Amico, C. D. Bruna, A. Grein, R. Mazzoleni, M. L. Ricciardi \& R. Tintinelli: Thaimycins, new anthelmintic and antiprotozoal antibiotics produced by Streptomyces michiganensis var. amylolyticus var. nova. Arch. Mikrobiol. 70: 197 210, 1970

19) SaKagami, Y.; A. Ueda \& S. YAMABayashi: Studies on ikutamycin, a new antifungal antibiotic. I. Isolation and properties of ikutamycin. J. Antibiotics 20:299 303, 1967

20) Ömura, S.; A. Nakagawa, K. Shibata \& H. Sano: The structure of hitachimycin, a novel macrocyclic lactam involving $\beta$-phenylalanine. Tetrahedron Lett. $23: 4713 \sim 4716,1982$

21) Ōiwa, R.; Y. IWai, Y. Takahashi, K. Kitao \& S. OMURA: Taxonomic studies of stubomycin-(hitachimycin)-producing actinomycete. Kitasato Arch. Exp. Med. 55: 119 124, 1982

22) Umezawa, I.; H. Takeshima, K. Kommama, Y. КоH, H. Yamamoto \& M. Kawaguchi: A new antitumor antibiotic, stubomycin. J. Antibiotics 34: 259 265, 1981

23) Omura, S.; H. Shimizu, Y. IwaI, K. Hinotozawa, K. Otoguro, H. Hashimoto \& A. Nakagawa: AM2604 A, a new antiviral antibiotic produced by a strain of Streptomyces. J. Antibiotics 35: 1632 1637, 1982

24) Omura, S.; K. Otoguro \& H. TanakA: The mode of action of a novel 18-membered macrolide, virustomycin A (AM-2604 A), on Trichomonas foetus. J. Antibiotics 36: 1755 1761, 1983

25) Ómura, S.; N. Imamura, K. Hinotozawa, K. Otoguro, G. Lukacs, R. Faghih, R. Tolmann, B. H. ARISON \& J. L. SMITH: The structure of virustomycin A. J. Antibiotics 36: 1783 1786, 1983

26) Renn, D. W.; M. Kugelman, W. P. Cullen \& K. V. Rao: BA-17039-A and -B: New cytotoxic and antibiotic substances. Antimicrob. Agents Chemother.-1963; 73 76, 1964

27) Hori, M.; E. Itō, T. Takita, G. Koyama, T. Takeuchi \& H. Umezawa: A new antibiotic, formycin. J. Antibiotics, Ser. A 17: 96 99, 1964

28) Koyama, G.; K. Maeda \& H. Umezawa: The structural studies of formycin and formycin B. Tetrahedron Lett. 1966: 597 602, 1966

29) Kikuchi, M.; K. Kumagai, N. Ishida, Y. Itō, T. Yamaguchi, T. Furumai \& T. Okuda: Isolation, purification, and properties of kikumycins A and B. J. Antibiotics, Ser. A 18:243 250, 1965

30) TakaIshi, T.; Y. Sugawara \& M. Suzuki: Structure of kikumycin A and B. Tetrahedron Lett. 1972: $1873 \sim 1876,1972$

31) Ömura, S.; Y. Ifat, A. Hirano, A. Nakagawa, J. Awaya, H. Tsuchiya, Y. Takahashi \& R. Masuma: 
A new alkaloid AM-2282 of Streptomyces origin. Taxonomy, fermentation, isolation and preliminary characterization. J. Antibiotics 30: 275 282, 1977

32) Furusaki, A.; N. Hashiba, T. Matsumoto, A. Hirano, Y. Iwal \& S. Ōmura: X-ray crystal structure of staurosporine: A new alkaloid from a Streptomyces strain. J. Chem. Soc. Chem. Commun. 1978: $800 \sim 801,1978$

33) Umezawa, H.; K. MAEdA \& A. KosAKA: Isolation of a new antibiotic substance, aureothricin from a strain of Streptomyces. Jpn. Med. J. 1: $512 \sim 517,1948$

34) Celmer, W. D.; F. W. Tanner, Jr., M. Harfenist, T. M. Lees \& I. A. Solomons: Characterization of the antibiotic thiolutin and its relationship with aureothricin. J. Am. Chem. Soc. 74: 6304 6305, 1952 